\title{
Molecular Components of Nitrogen Fixation Gene Cluster and Associated Enzymatic Activities of Non-Heterocystous Thermophilic Cyanobacterium Thermoleptolyngbya sp.
}

\author{
Meijin Li ${ }^{1}$, Lei Cheng $\left.{ }^{2}{ }^{(}\right)$, Jie Tang ${ }^{3}\left(\mathbb{D}\right.$ and Maurycy Daroch ${ }^{1, *(\mathbb{C})}$ \\ 1 School of Environment and Energy, Peking University Shenzhen Graduate School, 2199 Lishui Rd., \\ Shenzhen 518055, China; 1801213472@pku.edu.cn \\ 2 Beijing Engineering and Technology Research Center of Food Additives, Beijing Technology \& Business \\ University, Beijing 100048, China; chenglei@btbu.edu.cn \\ 3 School of Food and Bioengineering, Chengdu University, Chengdu 610106, China; tangjie@cdu.edu.cn \\ * Correspondence: m.daroch@pkusz.edu.cn
}

\section{check for}

updates

Citation: Li, M.; Cheng, L.; Tang, J.; Daroch, M. Molecular Components of Nitrogen Fixation Gene Cluster and Associated Enzymatic Activities of Non-Heterocystous Thermophilic Cyanobacterium Thermoleptolyngbya sp. Life 2021, 11, 640. https:// doi.org/10.3390/life11070640

Academic Editors:

Przemyslaw Malec, Rajesh Jha and Pengcheng Fu

Received: 1 June 2021

Accepted: 24 June 2021

Published: 30 June 2021

Publisher's Note: MDPI stays neutral with regard to jurisdictional claims in published maps and institutional affiliations.

Copyright: (c) 2021 by the authors. Licensee MDPI, Basel, Switzerland. This article is an open access article distributed under the terms and conditions of the Creative Commons Attribution (CC BY) license (https:/ / creativecommons.org/licenses/by/ $4.0 /)$.

\begin{abstract}
Thermoleptolyngbya is a genus of non-heterocystous cyanobacteria that are typical inhabitants of hot spring microbial mats. These filamentous cyanobacteria are capable of nitrogen fixation. In this study, we examined the genome sequences of five publicly available Thermoleptolyngbya strains to explore their nitrogen fixation gene cluster. Analysis of the nitrogen-fixation clusters in these extremophilic strains revealed that the cluster is located in a single locus in Thermoleptolyngbyace. The average nucleotide and amino acid identities of the nitrogen-fixation cluster combined with phylogenetic reconstructions support that nitrogen fixation genes in Thermoleptolyngbyaceae are closely related to one another but also heterogeneous within the genus. The strains from Asia, and China more specifically, generate a separate clade within the genus. Among these strains Thermoleptolyngbya sp. PKUAC-SCTB121 has been selected for experimental validation of clade's nitrogen fixation capacity. The acetylene reduction experiments of that strain shown that the strain can reduce acetylene to ethylene, indicating a fully functional nitrogenase. The activity of nitrogenase has been tested using different gas compositions across $72 \mathrm{~h}$ and exhibited a two-phase trend, high nitrogenase activity at the beginning of the assay that slowed down in the second phase of the analysis.
\end{abstract}

Keywords: biological $\mathrm{N}_{2}$ fixation; Nif genes; gene cluster; genome analysis; Thermoleptolyngbya; non-heterocystous cyanobacteria

\section{Introduction}

Biological $\mathrm{N}_{2}$ fixation (BNF) is the process in which atmospheric $\mathrm{N}_{2}$ gas is converted into ammonia nitrogen by a nitrogen-fixing microorganism. The nitrogen fixation is driven by a cluster of nif genes products that catalyze this important reaction [1]. The nitrogenase complex consists of two metalloprotein components of the molybdenum iron (MoFe) protein and iron ( $\mathrm{Fe}$ ) protein [2]. For the microorganisms that could perform BNF, cyanobacteria are the most diverse photosynthetic bacteria, widely distributed in various conditions, and play an essential role in the BNF.

A hot spring is a place where warm or hot groundwater springs from the Earth's crust on a regular basis for at least a predictable part of the year and is significantly above the average temperature. The water emanating from a hot spring is heated by geothermal heat. A previous study showed that genomes and metagenomes of cyanobacteria that form hot spring communities harbor a conserved nif gene cluster, suggesting that these strains have a potential to perform nitrogen fixation [3]. The role of individual microbes in nitrogen cycling as environmental conditions vary over space and time. The present upper-temperature limit for $\mathrm{N}_{2}$ fixation $\left(92^{\circ} \mathrm{C}\right)$ was reported in an organism isolated from a marine hydrothermal vent. The upper-temperature limit for $\mathrm{N}_{2}$ fixation in terrestrial environments is $82{ }^{\circ} \mathrm{C}$ [4]. 
Thermophilic cyanobacteria isolated from hot springs are increasingly studied due to their environmental and biotechnological importance [5,6]. Cyanobacteria exhibit remarkable diversity in their morphological structures and can be broadly divided into heterocystous and non-heterocystous based on their mode of nitrogen fixation. The $\mathrm{N}_{2}$-fixing system of non-heterocystous cyanobacteria markedly differs from that of heterocystous counterparts. Heterocystous filamentous cyanobacteria, such as Fischerella thermalis, have attracted early attention for their role in the cycling of nitrogen in thermal ecosystems [7]. Their mode of action is relatively well described [8]. The nitrogen-fixing capacity of non-heterocystous cyanobacteria in thermal ecosystems is less studied.

To some extent, the mechanisms of non-heterocystous cyanobacteria are more diverse [9]. This is especially important considering that non-heterocystous cyanobacteria cannot compartmentalize nitrogen fixation; therefore, an alternative mechanism to avoid the nitrogenase inhibition with oxygen need to be implemented in non-heterocystous strains [2,10]. Previous studies showed that there are various strategies to protect the enzyme complex against oxygen. For example, Trichodesmium sp., a marine filamentous cyanobacterium, exhibits exceptional ability to fix atmospheric nitrogen during the day. Whilst the strain does not differentiate into heterocysts, the localization of its Fe-protein of nitrogenase (dinitrogenase reductase) is confined to a limited subset of cells (on average $14 \%$ ) in the sections randomly distributed across the filaments. The nitrogenase containing cells perform the $\mathrm{O}_{2}$ protective function, but they are not bona fide heterocysts [11,12].

Recently a new genus of filamentous cyanobacteria, Thermoleptolyngbya was delineated from the polyphyletic Leptolyngbya, and several species have been proposed within this genus $[13,14]$. Strains of this genus are non-heterocystous, and they could play an essential role in the nitrogen cycle within thermal ecosystems, as recently suggested by a study on Thermoleptolyngbya sp. O-77, collected from hot springs of Kumamoto, Japan [15]. Thanks to the advances of modern DNA sequencing technology and genomics, analysis of the genetic information of both cyanobacterial isolates and genome assemblies extracted from metagenomic bins created during hot spring community sequencing is now feasible. The increased sequence pool allows for a better understanding of nitrogen fixation in the thermal niches [16]. Simultaneously, as new cyanobacterial strains are isolated from thermal sites worldwide [17], and their genetic modification systems are being developed $[18,19]$, experimental validation of sequence data is also increasingly possible. Interestingly, complete nitrogen fixation gene clusters have been identified in the genomes of Thermoleptolyngbya, which could be particularly interesting considering their ability to thrive in thermal environments. It also suggests that they are capable of providing nitrogen to the microbial mats they are inhabiting. These advances make Thermoleptolyngbya genus potentially interesting for studying nitrogen fixation among thermophilic non-heterocystous cyanobacteria and complement the work done on heterocystous thermal strains belonging to Fisherella.

In this study, we used the whole genome sequence of five Thermoleptolyngbya strains deposited in the public databases; compared and assessed their nitrogen-fixation gene cluster information. To complement bioinformatic analysis, we have selected an isolate Thermoleptolyngbya PKUAC-SCTB121, isolated from hot springs of Ganzi prefecture, Sichuan, China, from our culture collection as a representative of the genus and assessed its acetylene reduction capacity to provide experimental evidence of their nitrogen-fixing capability.

\section{Materials and Methods}

\subsection{Genomic Sequence Information}

All the sequence data used in this study were downloaded from NCBI Database. Table 1 shows their Genebank numbers (Table 1). Strains PKUAC-SCTB121 and PKUACSCTA183 (hereafter B121 and A183, respectively) were sequenced, assembled and annotated by our group using a hybrid sequencing approach [14]. 
Table 1. Origin and accession numbers of Thermoleptolyngbya sp. genomes.

\begin{tabular}{|c|c|c|c|}
\hline Strain & Accession Number & Genome Description & Strain Origin \\
\hline $\begin{array}{l}\text { Thermoleptolyngbya sp. } \\
\text { PKUAC-SCTB121 }\end{array}$ & СР070366.1 & $\begin{array}{l}\text { Complete genome } \\
\text { sequence }\end{array}$ & $\begin{array}{l}30^{\circ} 15^{\prime} 57^{\prime \prime} \mathrm{N} \\
101^{\circ} 56^{\prime} 55^{\prime \prime} \mathrm{E}\end{array}$ \\
\hline $\begin{array}{l}\text { Thermoleptolyngbya sp. } \\
\text { PKUAC-SCTA83 }\end{array}$ & СР053661 & $\begin{array}{l}\text { Complete genome } \\
\text { sequence }\end{array}$ & $\begin{array}{l}30^{\circ} 05^{\prime} 14^{\prime \prime} \mathrm{N} \\
101^{\circ} 52^{\prime} 24^{\prime \prime} \mathrm{E}\end{array}$ \\
\hline $\begin{array}{l}\text { Thermoleptolyngbya sp. } \\
\text { O-77 }\end{array}$ & AP017367 & $\begin{array}{l}\text { Complete genome } \\
\text { sequence }\end{array}$ & $\begin{array}{l}32^{\circ} 48^{\prime} 11^{\prime \prime} \mathrm{N} \\
130^{\circ} 42^{\prime} 28^{\prime \prime} \mathrm{E}\end{array}$ \\
\hline $\begin{array}{l}\text { Thermoleptolyngbya sp. } \\
\text { C42_A2020 }\end{array}$ & JACYLP000000000.1 & Metagenomic bin & $\begin{array}{l}29^{\circ} 69^{\prime} 00^{\prime \prime} \mathrm{N} \\
83^{\circ} 68^{\prime} 00^{\prime \prime} \mathrm{E}\end{array}$ \\
\hline $\begin{array}{c}\text { Thermoleptolyngbya sp. } \\
\text { M55_K2018 }\end{array}$ & DVEA00000000.1 & Metagenomic bin & $\begin{array}{l}39^{\circ} 51^{\prime} 00^{\prime \prime} \mathrm{S} \\
72^{\circ} 50^{\prime} 00^{\prime \prime} \mathrm{W}\end{array}$ \\
\hline
\end{tabular}

\subsection{Nitrogen Fixation Gene Cluster, ANI and AAI Analysis}

The nitrogen fixation gene cluster containing 27 well-defined genes and 2 unknown hypothetical proteins was extracted from the B121 genome combined with the results published elsewhere [15] and the annotation data of strains used in this study. The 29 genes were mapped against four other Thermoleptolyngbya sp. strains using Geneious mapper (Biomatters, Melbourne, Australia) on default settings. All genes of the nitrogen fixation cluster were extracted, then 25 genes of each strain were concatenated as one string. The Average Nucleotide Identity (ANI) and Average Amino Acid Identity (AAI) analyses between these five concatenated strings were performed by an online tool devised by Kostas lab (Available at http:/ / enve-omics.ce.gatech.edu/ accessed on 15 June 2021 [20]).

\subsection{Phylogenetic Analysis and KEGG Pathway}

MEGA-X software 10.1.7 (Available at https:/ / www.megasoftware.net/ accessed on 17 June 2021) [21] was used to perform phylogenetic analyses of nif $\mathrm{H}$ and $16 \mathrm{~S}$ rRNA genes. A total of 19, both heterocystous and non-heterocystous cyanobacteria, were assessed for the relationships of their nif $\mathrm{H}$ genes using the Maximum Likelihood method, parameters were set according to Tang [22]. 16S rRNA of 18 heterocystous and non-heterocystous cyanobacteria strains was used to perform a phylogenetic analysis to indicate the evolutionary relationship. Metagenomic bins belonging to strains Thermoleptolyngbya sp. C42_A2020 from Chile and Thermoleptolyngbya sp. M55_K2018 from India were excluded from the 16S analysis due to lack of sequence availability. Concatenated 25 genes of nitrogen gene cluster were used to perform MLSA (Multi Locus Sequence Analysis). The predicted gene-coding sequences were submitted to KEGG database, and the resultant metabolic pathway of nitrogen-fixation was analyzed.

\subsection{B121 Cultivation and Maintenance}

The strain B121 used in the experiment was collected from the hot spring in Ganzi Prefecture [17]. The GPS location is $30^{\circ} 15^{\prime} 57^{\prime \prime} \mathrm{N}, 101^{\circ} 52^{\prime} 24^{\prime \prime}$ E (Figure 1); and the temperature range is $53.1^{\circ} \mathrm{C}$; the environmental $\mathrm{pH}$ range is 6.35 [5,17]. The strain was cultured with BG-11 medium [23] and stored in a constant temperature light incubator. The relevant conditions of the incubator are set: temperature is $45^{\circ} \mathrm{C}$, light intensity is 2000 lux, photoperiod 16L:8D. 


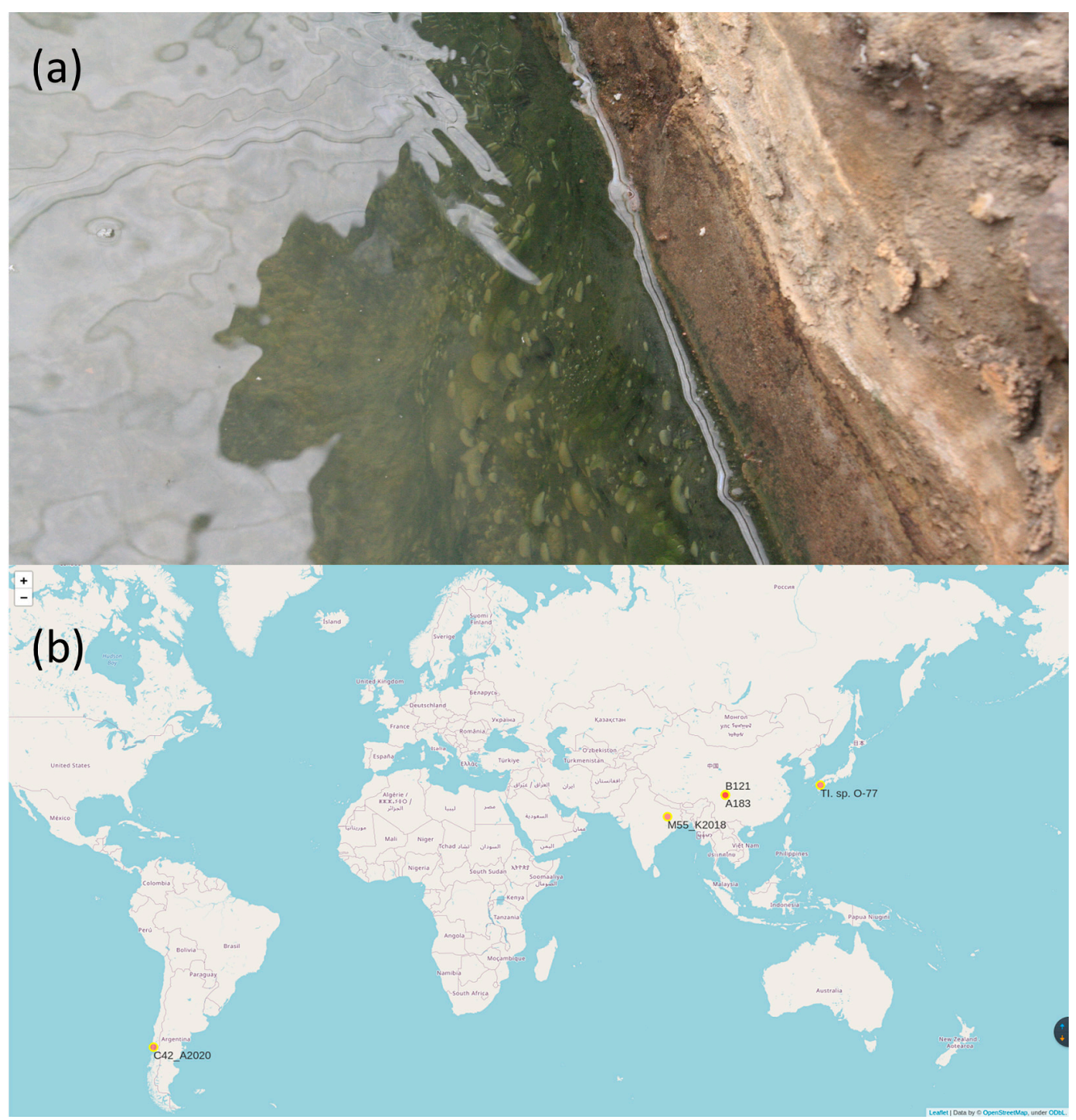

Figure 1. (a) Presents the sampling site of B121 strain, and a microbial mat in the pond from which the strain was isolated; (b) the geographical distribution of five strains analysed in this study.

\subsection{B121 Electron Microscopy}

Electron microscopy has been performed essentially as described elsewhere [14]. Briefly, after harvesting, the cells were sequentially fixed using SEM fixative (Servicebio, Wuhan, China), post-fixed with 0.1M phosphate buffer ( $\mathrm{pH}$ 7.4), dehydrated with a gradient of ethanol, dried with Critical Point Dryer, and coated with a conductive metal coating. Cells were observed under a scanning electron microscope (SEM) (HITACHI, SU8100). SEM micrographs of strain B121 were obtained with 3000× magnification. For transmission electron microscopy (TEM) cells were fixed in TEM fixative (Servicebio, Wuhan, China), post-fixed, and dehydrated, and embedded in resin. Finally, the embedded cells were cut 60-80 nm thin slices using an ultra-microtome and stained. Cells were observed under a transmission electron microscope (TEM) (HT7800/HT7700, Hitachi, Tokyo, Japan) to obtain images of strain B121 with a 7000 $\times$ magnification (Wuhan Service Biotechnology Co. Ltd., Wuhan, China).

\subsection{B121 Nitrogenase Assay}

Cells of B121 pre-cultured in the nitrate-containing, standard BG-11 medium, were washed twice with nitrate-free medium (Stock 1 of BG-11 medium was replaced by ultra-pure water of equal volume). The washed cells were used under all experimental conditions. Nitrogenase assay methodology was adapted from Chen et al. [24]. Under nitrate-free conditions, 
cells resuspended in nitrate-free BG-11 were grown under three different $\mathrm{N}_{2}$ concentrations in inert gas mixtures: $\left(\mathrm{Ar} / \mathrm{N}_{2} / \mathrm{CO}_{2}=79 / 20 / 1[v / v / v \%]\right),\left(\mathrm{Ar} / \mathrm{N}_{2} / \mathrm{CO}_{2}=90 / 9 / 1[v / v / v \%]\right)$, and $\left(\mathrm{Ar} / \mathrm{CO}_{2}=99 / 1[v / v \%]\right)$. The cylindrical vials of the total volume of $60 \mathrm{~mL}$ were filled with $20 \mathrm{~mL}$ of culture to provide sufficient headspace for sampling; flushed for $5 \mathrm{~min}$ with each of the different gas mixtures; and subsequently tightly sealed with rubber septum seals. Cell cultures were grown under the 12L:12D photoperiod under the illumination of $30 \mu \mathrm{mol} \mathrm{m}{ }^{-2} \mathrm{~s}^{-1}$ at $45^{\circ} \mathrm{C}$, without shaking. Samples were collected and used to measure acetylene reduction in $12 \mathrm{~h}$ time intervals during the culture period of $72 \mathrm{~h}$. The assay was initiated using an injection of $2 \mathrm{~mL}$ of acetylene gas, and nitrogenase activity was assessed based on the acetylene reduction reaction. Gaseous products were collected into the air pockets and sealed immediately. Air pockets were collected, and ethylene concentration was measured using a gas chromatography-hydrogen ion flame detector/mass spectrometry detector GC2014C (Shimadzu, Kyoto, Japan) by Qingdao BYNE Testing Technology Services Co., Ltd.

\section{Results}

\subsection{Nitrogen Fixation Gene Cluster, ANI and AAI Analysis \\ 3.1.1. Nitrogen Fixation Gene Cluster}

The result showed that B121, A183, Thermoleptolyngbya sp. O-77, and Thermoleptolyngbya sp. C42_A2020 contained 29 conserved genes involved in the nitrogen fixation gene cluster (Supplementary Materials Figure S1, Table 2), as well as hypothetical proteins between those 29 genes. The nif genes of the FeMo cofactor synthesis and maturation components were identified in the genome sequences of these four strains. The nif gene cluster was divided into two regions with different transcriptional directions in all strains analysed, showing significant consistency of that genomic fragment (Supplementary Materials Figure S1). The nifHDK genes were located centrally in the nitrogen fixation gene cluster (Figure 2). The fifth strain analysed, Thermoleptolyngbya sp. M55_K2018 had only 19 nitrogen fixation genes, lacking all-important: nifK, nifD, nifEN, nifZ, mopII, and tellurite resistance protein TehB, genes. The detailed analysis of the sequences suggests that this metagenome-assembled draft genome is incomplete and should be completed before final conclusions could be made. The KEGG analysis of the obtained data suggests that except for the incomplete M55 genome, all other strains exhibited a fully functional nitrogen fixation pathway (Supplementary Materials Figures S2-S5).

Table 2. The 29 genes of nitrogen fixation cluster in Thermoleptolyngbya.

\begin{tabular}{ccc}
\hline $\begin{array}{c}\text { Gene Name } \\
\text { (B121 Convention) }\end{array}$ & Length $(\mathbf{b p})$ & Function or Putative Function \\
\hline helix-turn-helix domain (cnfR) & 1599 & Transcriptional regulator \\
(2Fe-2S) ferredoxin domain & 654 & (2Fe-2S) ferredoxin domain-containing protein \\
nifT & 204 & putative nitrogen fixation protein \\
NifV(leuA) & 1122 & Homocitrate or 2-isopropylmalate synthase \\
dps & 543 & DNA starvation/stationary phase protection protein \\
Hypothetical protein & 477 & NifX-associated protein \\
NifX & 426 & Nitrogen fixation protein \\
NifEN & 2760 & bifunctional nitrogenase iron-molybdenum cofactor biosynthesis \\
protein NifEN
\end{tabular}


Table 2. Cont.

\begin{tabular}{ccc}
\hline $\begin{array}{c}\text { Gene Name } \\
\text { (B121 Convention) }\end{array}$ & Length $\mathbf{( b p )}$ & Function or Putative Function \\
\hline nifH & 876 & Nitrogenase iron protein \\
nifU & 906 & Fe-S cluster assembly protein \\
nifS & 1194 & Cysteine desulfurase \\
4Fe-4S (yfhL) & 375 & 4Fe-4S binding protein \\
nifB & 1491 & nitrogenase cofactor biosynthesis protein NifB \\
cysE (nifP) & 726 & serine O-acetyltransferase \\
Hypothetical protein & 267 & unknown \\
Hypothetical protein & 219 & unknown \\
NifW & 318 & nitrogenase-stabilizing/protective protein \\
HesA $/$ MoeB/ThiF & 783 & Molybdopterin-synthase adenylyltransferase \\
iscA (hesB) & 369 & iron-sulfur cluster assembly accessory protein \\
(2Fe-2S) fdxH & 303 & ferrous iron transport protein A \\
FeoA & 312 & Flavodoxin \\
isiB & 531 & nitrogenase-associated protein \\
ArsC & 414 & tellurite resistance protein \\
TehB & 603 & Molybe-2S iron-sulfur cluster binding domain-containing protein \\
mopII & 210 &
\end{tabular}

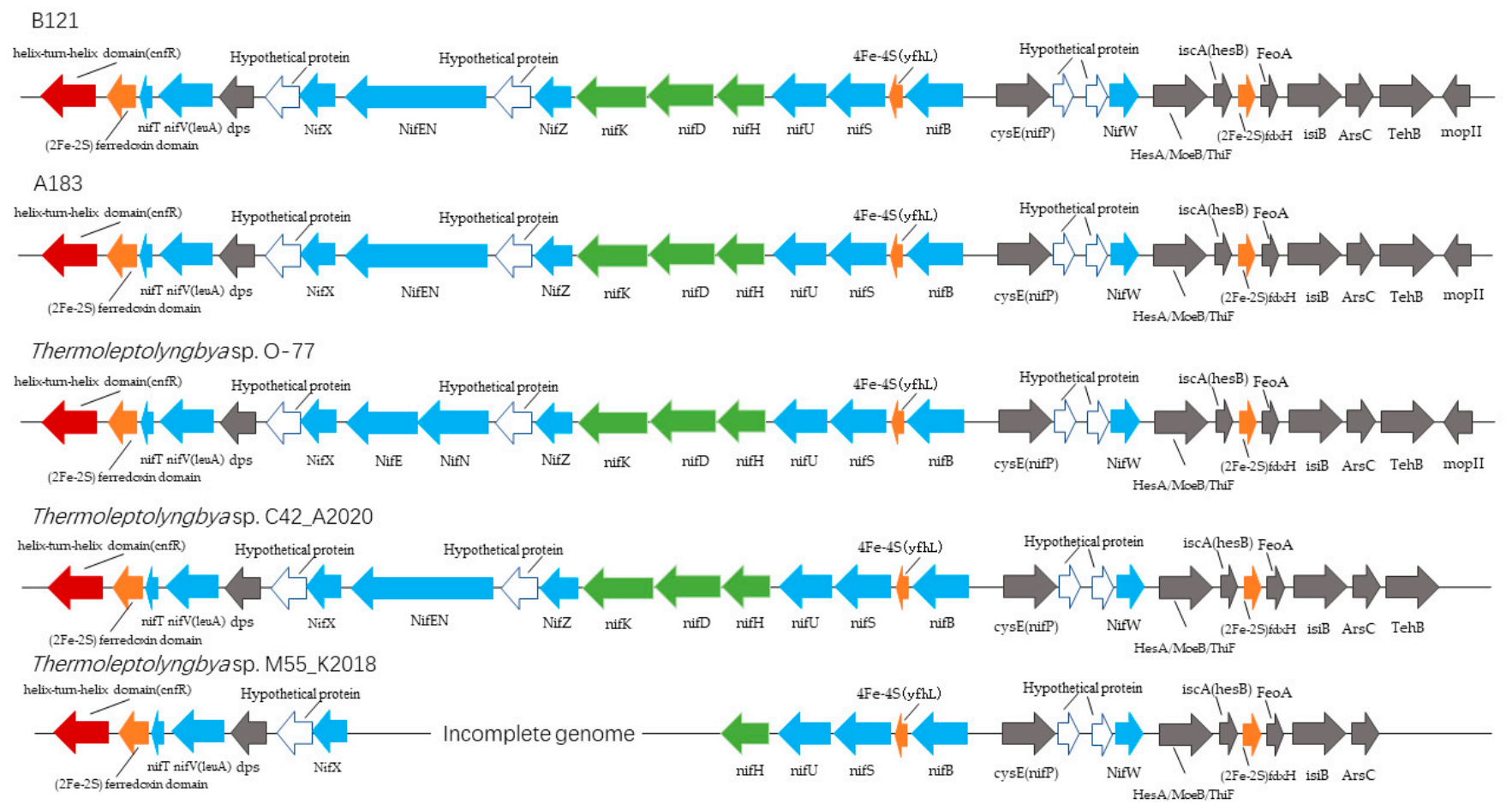

Figure 2. Nitrogen fixation gene clusters of Thermoleptolyngbya strains.

\subsubsection{ANI and AAI Analysis}

Average Nucleotide (ANI, Table 3) and Amino Acid (AAI, Table 4) of concatenated sequences of the 25-long gene cluster suggest that nitrogen-fixation cluster in Thermoleptolyngbya strains is conserved. The two Sichuan strains show the highest identity at both nucleotide and amino acid level, followed by Japanese strain O-77. More geographically distant strains show lower similarities. Interestingly, whilst at the nucleotide level, the Chinese and Japanese strains of Thermoleptolyngbya are near identical, there is a greater divergence at the amino acid level, suggesting a selection pressure for amino acid change between these strains. 
Table 3. ANI analysis for concatenated 25 genes for five strains.

\begin{tabular}{cccccc}
\hline ANI Identity & B121 & A183 & O-77 & C42_A2020 & M55_K2018 \\
\hline B121 & & 99.95 & 93.97 & 93.84 & 95.54 \\
A183 & 99.95 & & 93.87 & 94.02 & 95.23 \\
O-77 & 93.97 & 93.87 & & 98.10 & 94.96 \\
C42_A2020 & 93.84 & 94.02 & 98.10 & & 95.23 \\
M55_K2018 & 95.54 & 95.23 & 94.96 & 95.23 & \\
\hline
\end{tabular}

Table 4. AAI analysis for concatenated 25 genes for five strains.

\begin{tabular}{cccccc}
\hline AAI Identity & B121 & A183 & O-77 & C42_A2020 & M55_K2018 \\
\hline B121 & & 99.90 & 95.95 & 96.87 & 96.64 \\
A183 & 99.90 & & 96.18 & 96.69 & 97.36 \\
O-77 & 95.95 & 96.18 & & 98.77 & 95.98 \\
C42_A2020 & 96.87 & 96.69 & 98.77 & & 96.92 \\
M55_K2018 & 96.64 & 97.36 & 95.98 & 96.92 & \\
\hline
\end{tabular}

\subsection{Phylogenetic Analysis}

Several phylogenetic trees have been constructed to position Thermoleptolyngbya strains among other nitrogen-fixing cyanobacteria. Analysis of the $16 \mathrm{~S}$ phylogeny separates the strains into three well-defined clades of filamentous heterocystous and non-heterocystous strains, with unicellular cyanobacteria forming an outgroup. Among filamentous nonheterocyst forming strains, the strains separate into Leptolyngbya (Leptolyngbyaceae) and Thermoleptolybya (Ocullatelaceae). Within the Thermoleptolybya clade, the two strains isolated from Ganzi prefecture of Sichuan province separate from the Japan-originated O-77 (Figure 3). The heterocyst-forming strains follow the previously published distribution [25]. Phylogenetic analysis of the nifH gene for 19 strains presented in Figure 4 showed that all five strains of Thermoleptolybya formed a well-defined clade along with other nonheterocystous cyanobacteria. Interestingly, strains that belong to the Leptolyngbya clade separated into two distinct clades showing higher divergence.

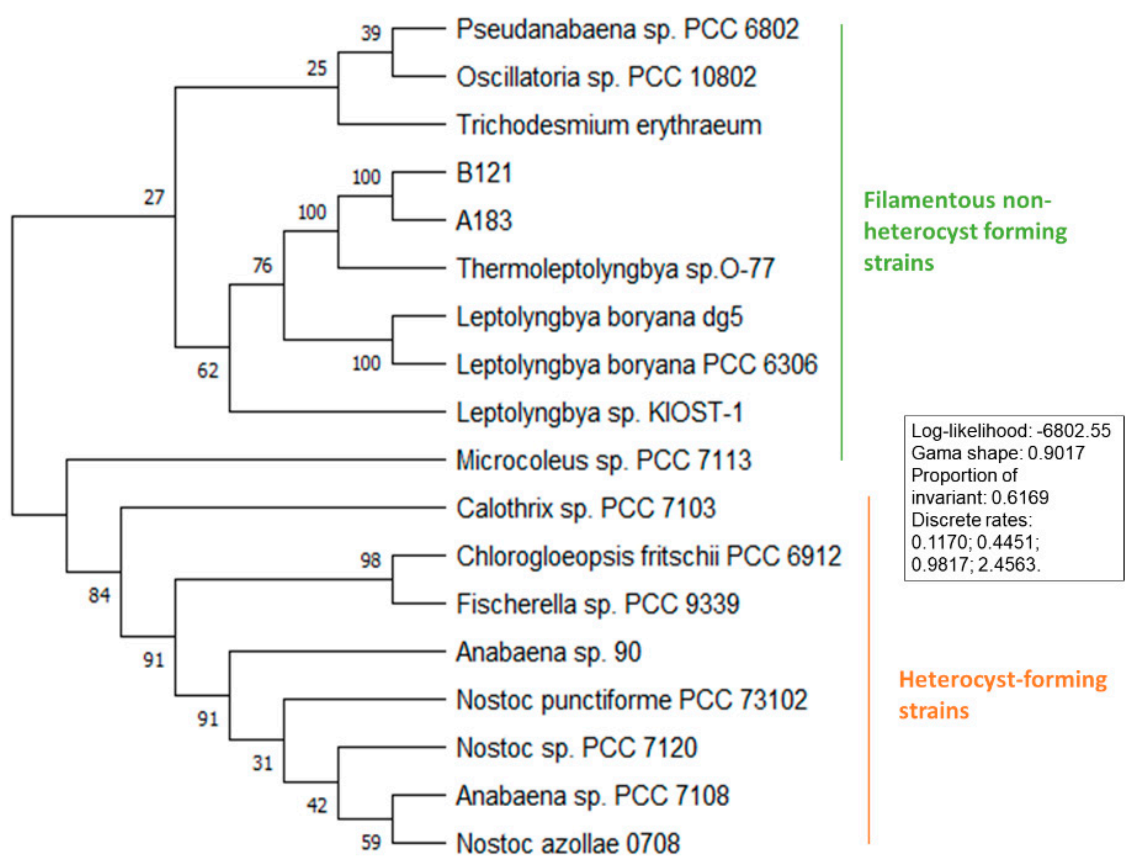

Figure 3. Phylogenetic tree of $16 \mathrm{~S}$ rRNA gene. 


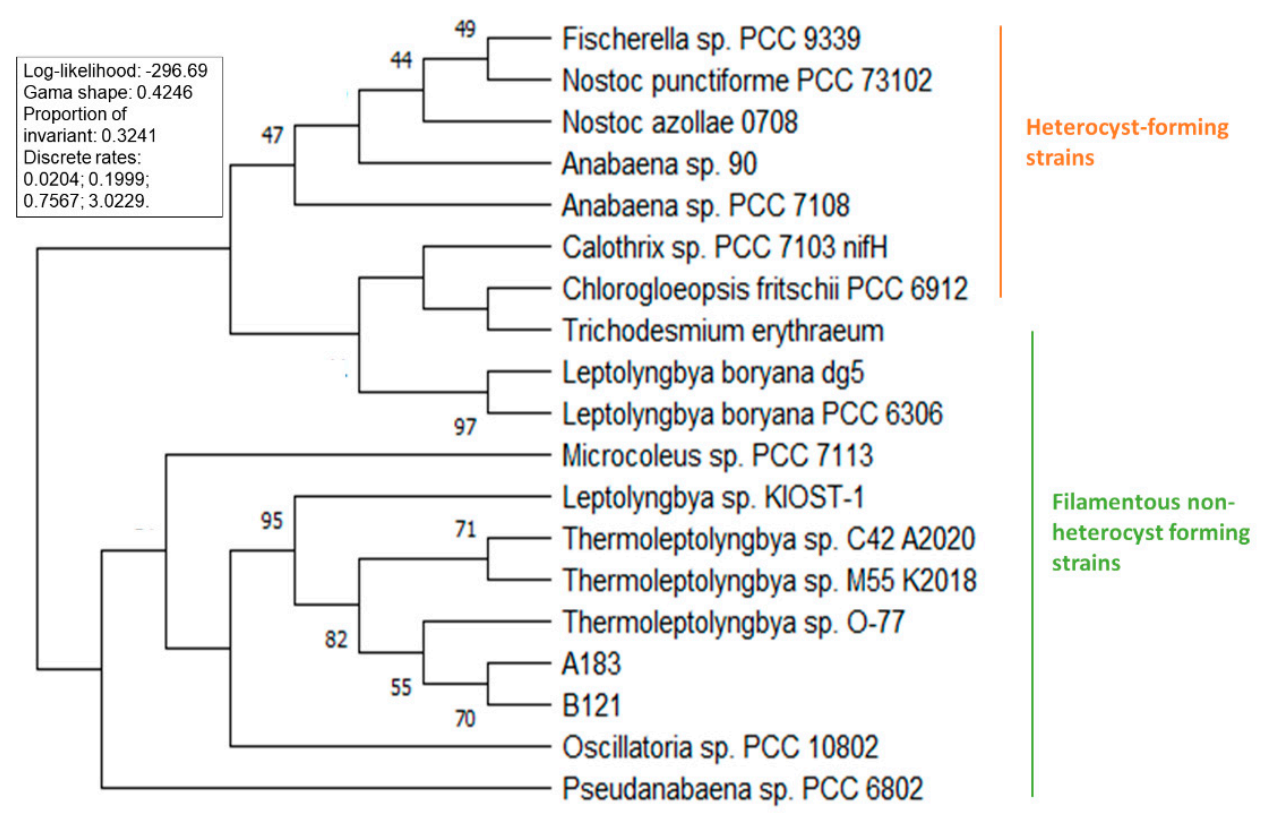

Figure 4. Phylogenetic tree of nifH gene.

Finally, the MLSA phylogenetic tree (Figure 5) also showed these four strains clustered well whilst maintaining divergence of Sichuan strains from the strains isolated from Japan (O 77), Chile (C42) and India (M55). Thermoleptolyngbya sp. M55_K2018 lacked six genes, including essential nifD and nifK. These genes were therefore excluded from this analysis throughout the dataset to maintain the maximal strain number for the analysis.

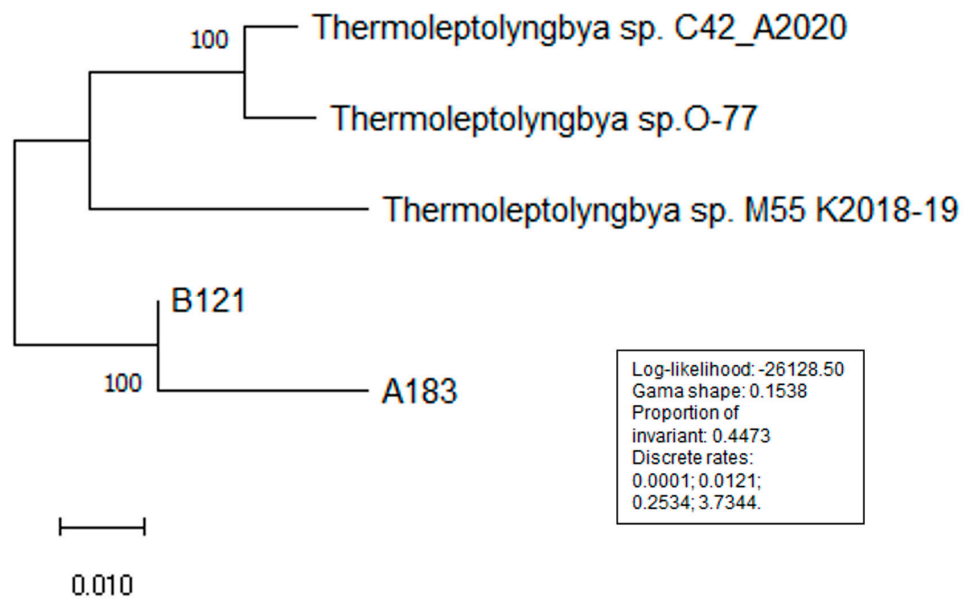

Figure 5. MLSA analysis for 25 genes of nitrogen fixation gene cluster.

\subsection{Morphological Investigation of B121}

Figure 6 presents the cells of Thermoleptolybya sp. B121 grown under nitrogen fixation conditions. It can be seen from the figure that the B121 did not differentiate into heterocysts, supporting the earlier claims that the B121 is a non-heterocytous cyanobacterium. Besides, according to SEM pictures, the appearance of B121 under nitrogen-fixation conditions did not differ from the strain grown under nitrate-replete conditions, which also shows that the nitrogen fixation capacity had little effect on the cell morphology. In addition, TEM picture showed a cyanophycin granule, which is associated with nitrogen storage, one of the mechanisms of how B121 cells store nitrogen; the relevant synthase has also been identified in the organism's genome. 

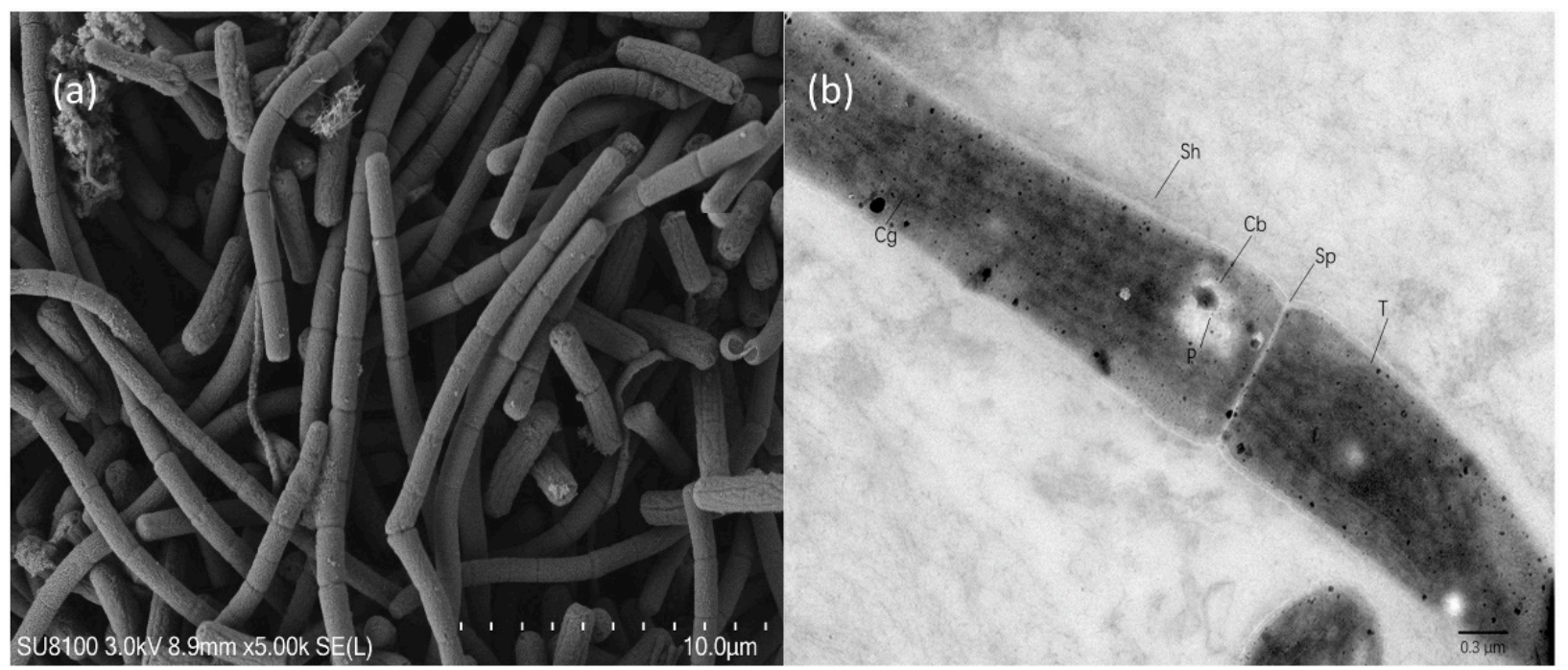

Figure 6. (a) SEM picture showing cells of B121 under acetylene reduction condition; (b) TEM picture of B121 (Cb carboxysome, Cg cyanophycin granule, P polyphosphate body, Sh sheath, Sp septum, T thylakoid).

\subsection{Nitrogenase Activity of Cell Suspensions of Thermoleptolyngbya sp. B121 Cells}

Considering that based on comparative genomic analysis, Thermoleptolyngbya strains form distinct clades using 16S, nifH and MLSA methodology Thermoleptolyngbya sp. B121 was selected as a representative strain for further study and assessment of its nitrogen fixation ability. To study the nitrogen fixation capacity of the cell suspensions the acetylene reduction activity test was used. The experiment was performed at the temperature of $45^{\circ} \mathrm{C}$ and light intensity of $30 \mu \mathrm{mol} \mathrm{m}{ }^{-2} \mathrm{~s}^{-1}$, both physiological to that strain [17]. Two nitrogen concentrations were tested, 9 and $20 \%(v / v)$, and the strain's ability to reduce acetylene to ethylene was analyzed in the course of $72 \mathrm{~h}$. Throughout the experiment, the amount of acetylene that has been reduced to ethylene has been steadily increasing (Figure 7a) and its amount was proportional to the concentration of nitrogen in the gas mixture. Moreover, a steady increase of ethylene content was observed regardless of the lighting conditions suggesting that cells were unlikely to photosynthesize during the assay. After $72 \mathrm{~h}$, the ethylene content reached $81,159 \mathrm{nmol} / \mathrm{g}$ for the lower concentration of nitrogen. When the gas composition was $\mathrm{Ar} / \mathrm{N}_{2} / \mathrm{CO}_{2}=79 / 20 / 1[v / v / v \%]$, the amount of acetylene being reduced to ethylene increased. At the 72 th hour, the ethylene content reached $184,618 \mathrm{nmol} / \mathrm{g}$. Figure $6 \mathrm{~b}$ shows that nitrogen concentration in the gas phase had a significant impact on the acetylene reduction assay. A direct correlation between the availability of nitrogen and detected in cellular suspensions enzymatic activity of the nitrogenase assessed with a proxy assay employing acetylene reduction could be observed. Analysis of the time course nitrogenase cellular suspension activity (Figure $7 \mathrm{~b}$ ) revealed that enzymatic activity assessed with acetylene reduction assay remains relatively stable at values of approximately $1000 \mathrm{nmol} / \mathrm{g} / \mathrm{h}$ for a lower concentration of the nitrogen gas $\mathrm{Ar} / \mathrm{N}_{2} / \mathrm{CO}_{2}=90 / 9 / 1[v / v / v \%]$. Meanwhile, at higher concentration, i.e., $\mathrm{Ar} / \mathrm{N} 2 / \mathrm{CO} 2=79 / 20 / 1[v / v / v \%]$, the enzymatic activity starts from much higher values and subsequently stabilizes after $48 \mathrm{~h}$ of the assay by dropping by approximately $25 \%$ to $2400 \mathrm{nmol} / \mathrm{g} / \mathrm{h}$. The initial concentration of $\mathrm{N}_{2}$ in the gaseous mixture is likely therefore to have an impact on detected nitrogenase activity of cellular suspensions and probably on the expression and/or activation of the nitrogen fixation pathway. 

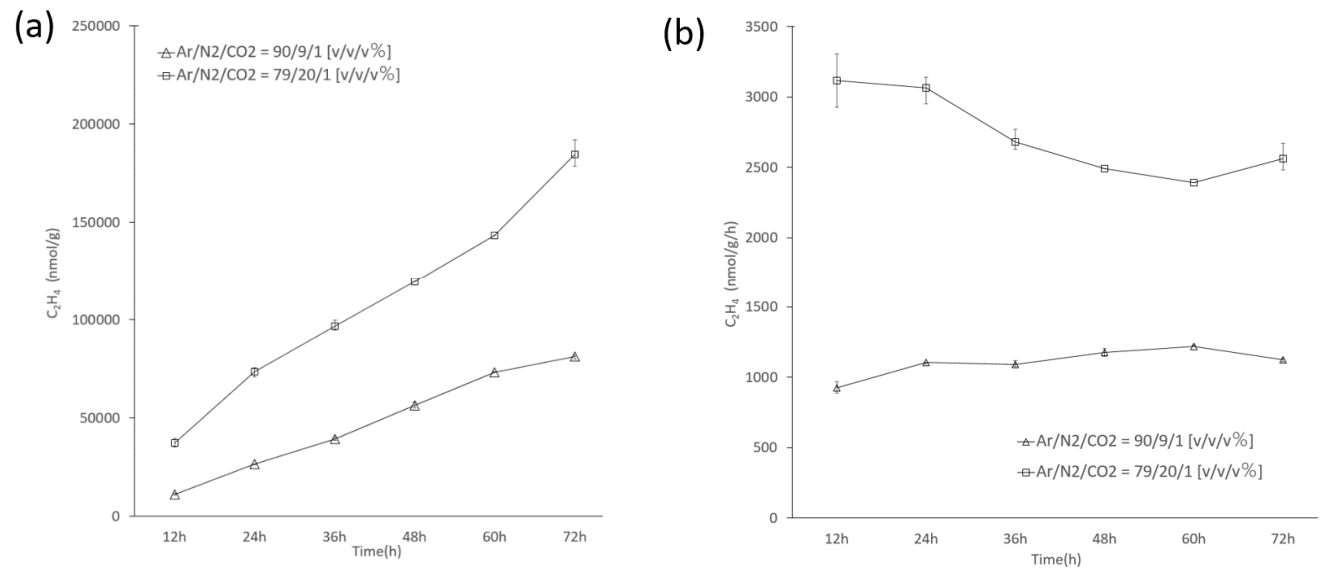

Figure 7. Acetylene reduction assay performed by cultures of Thermoleptolyngbya sp. B121 grown under different nitrogen concentrations (a) Cumulative ethylene production ( $\mathrm{nmol} / \mathrm{g}_{\text {biomass }}$ ) of cultures of Thermoleptolyngbya sp. B121; (b) Average ethylene production (nmol/g $\mathrm{g}_{\text {biomass }} / \mathrm{h}$ ) of the strain Thermoleptolyngbya sp. B121 per unit time of cultivation.

\section{Discussion}

The results have shown that the nitrogen-fixation cluster, situated in a single genomic locus, including key enzymes of nif gene operon in Thermoleptolyngbya strains, is relatively conserved within the genus. Although strain Thermoleptolyngbya sp. M55_K2018 lacks six of the essential genes, the identity of its remaining genes of the cluster follows other strains of the genus. It is reasonable to analyze them again when the complete genome of Thermoleptolyngbya sp. M55_K2018 becomes available. Simultaneously its components are similar to other nitrogen-fixing organisms that operate nif operon $[10,25]$.

Analysis of the nitrogenase activity of the selected B121 strain revealed that the strain is likely to possess a fully functional nitrogenase system based on its ability to reduce acetylene to ethylene. Interestingly activity of the enzyme depends on the initial concentration of the molecular nitrogen in the reaction mixture. These findings are consistent with previous findings on Thermoleptolyngbya sp. O-77 [15], where nitrogenase activities at $9 \%$ nitrogen and $20 \%$ nitrogen were markedly different. Analysis of the time course of nitrogenase activity throughout the $72 \mathrm{~h}$ period is different from that of the O-77 strain. The activity of the nitrogen-fixing enzyme shows relatively stable activity throughout an entire experiment and fails to follow the circadian pattern of the O-77 strain [15]. Similar results have been found in other cyanobacteria, namely Symploca PCC 8002 that exhibited the ability of nitrogen fixation under photosynthetic conditions through compartmentalization of nitrogenases in only a part of the cells forming a filament [26]. Meantime, the filamentous non-heterocystous cyanobacterium Schizothrix, isolated from a hot spring in Spain, showed that its $\mathrm{N}_{2}$ fixation in the light was significantly increased by an inhibitor of PSII and oxygen evolution, DCMU (3-(3,4-dichlorophenyl)-1,1-dimethylurea), and anaerobic conditions while no nitrogenase activity was found in the dark [27]. Conversely, studies of the non-heterocystous cyanobacterium, Leptolyngbya nodulosa shown through acetylene reduction assays that these cultures fixed nitrogen in the dark period of a diurnal cycle [28]. Therefore, it would be interesting to explore if a similar mechanism is typical for Thermoleptolyngbya sp. Similarly, there were earlier reports of aerobic nitrogenase activity shown by Trichodesmium NIBB1067. Even at a partial pressure of oxygen $\left(\mathrm{Po}_{2}\right)$ of $\sim 3 \mathrm{~atm}$, the acetylene reduction by Trichodesmium sp. remained at half of the maximum, similarly to results obtained for heterocystous cyanobacteria. [29]. Additionally, nitrogenase of Leptolyngbya nodulosa could also be active under micro-oxygenic conditions [28]. An alternative explanation of the phenomenon could be the cohabitation of heterotrophic bacterium that could consume the oxygen from photosynthetic culture and creating a micro-oxygenic environment to allow uninterrupted nitrogen fixation by the hot spring cyanobacterium. 
Further studies are required to explore the non-circadian character of nitrogenase activity in Thermoleptolyngbya strains of Ganzi.

\section{Conclusions}

All five genome sequences of Thermoleptolyngbya shared a common nitrogen fixation gene cluster reinforcing the claim that the genus belongs to thermophilic non-heterocystous nitrogen-fixing cyanobacteria. Analyses of the gene cluster sequences revealed that strains are likely to possess a fully functional nitrogen-fixation gene cluster. Moreover, all five strains show a close evolutionary relationship between one another and cluster together on common phylogenetic tree branches. Within the Thermoleptolyngbya genus, the strains isolated from Sichuan province of China form a separate group using both standard taxonomic markers and their nitrogen fixation gene cluster. Experimental validation of the nitrogen-fixing capacity further reinforces the claim about the functionality of the pathway. The results have shown that Thermoleptolyngbya sp. strain is capable of nitrogen fixation at elevated temperatures characteristic of hot spring ecosystems. Finally, the non-circadian pattern of nitrogenase activity in this strain should be explored in the future.

Supplementary Materials: The following are available online at https://www.mdpi.com/article/10 .3390/life11070640/s1, Figure S1: Gene cluster of strains in this study, Figures S2-S5: KEGG pathway of nitrogen metabolism for strain B121, A183, Thermoleptolyngbya sp. O-77, Thermoleptolyngbya sp. C42_A2020.

Author Contributions: Conceptualization, M.L., J.T., M.D.; methodology, J.T., L.C., M.D.; software, M.L., L.C.; validation, M.L., J.T.; formal analysis, M.L.; investigation, M.L.; resources, J.T., L.C., M.D.; data curation, M.L.; writing—original draft preparation, M.L.; writing—review and editing, M.L., J.T., L.C., M.D.; visualization, M.L.; supervision, J.T., M.D.; project administration, J.T., M.D.; funding acquisition, J.T., L.C., M.D. All authors have read and agreed to the published version of the manuscript.

Funding: This research was funded by Shenzhen Knowledge and Innovation Basic Research Grant number [JCYJ20180302153648993], Beijing Engineering and Technology Research Center of Food Additives (2002101) and National Natural Science Foundation of China (31970092, 32071480).

Institutional Review Board Statement: Not applicable.

Informed Consent Statement: Not applicable.

Data Availability Statement: Publicly available datasets were analyzed in this study. This data can be found here: CP070366; CP053661; AP017367; JACYLP000000000.1; DVEA00000000.1.

Conflicts of Interest: The authors declare no conflict of interest.

\section{References}

1. Thiel, T. Organization and regulation of cyanobacterial nif gene clusters: Implications for nitrogenase expression in plant cells. FEMS Microbiol. Lett. 2019, 366, 1-8. [CrossRef]

2. Fay, P. Oxygen relations of nitrogen fixation in cyanobacteria. Microbiol. Rev. 1992, 56, 340-373. [CrossRef] [PubMed]

3. Steunou, A.S.; Bhaya, D.; Bateson, M.M.; Melendrez, M.C.; Ward, D.M.; Brecht, E.; Peters, J.W.; Kühl, M.; Grossman, A.R. In situ analysis of nitrogen fixation and metabolic switching in unicellular thermophilic cyanobacteria inhabiting hot spring microbial mats. Proc. Natl. Acad. Sci. USA 2006, 103, 2398-2403. [CrossRef]

4. Hamilton, T.L.; Lange, R.K.; Boyd, E.S.; Peters, J.W. Biological nitrogen fixation in acidic high-temperature geothermal springs in Yellowstone National Park, Wyoming. Environ. Microbiol. 2011, 13, 2204-2215. [CrossRef] [PubMed]

5. Tang, J.; Liang, Y.; Jiang, D.; Li, L.; Luo, Y.; Shah, M.R.; Daroch, M. Temperature-controlled thermophilic bacterial communities in hot springs of western Sichuan, China. BMC Microbiol. 2018, 18, 1-14. [CrossRef] [PubMed]

6. Liang, Y.; Kaczmarek, M.B.; Kasprzak, A.K.; Tang, J.; Shah, M.M.R.; Jin, P.; Klepacz-Smółka, A.; Cheng, J.J.; Daroch, M. Thermosynechococcaceae as a source of thermostable C-phycocyanins: Properties and molecular insights. Algal Res. 2018, 35, 223-235. [CrossRef]

7. Alcorta, J.; Vergara-Barros, P.; Antonaru, L.A.; Alcamán-Arias, M.E.; Nürnberg, D.J.; Díez, B. Fischerella thermalis: A model organism to study thermophilic diazotrophy, photosynthesis and multicellularity in cyanobacteria. Extremophiles 2019, 23, 635-647. [CrossRef] 
8. Miyamoto, K.; Hallenbeck, P.C.; Benemann, J.R. Nitrogen Fixation by Thermophilic Blue-Green Algae (Cyanobacteria): Temperature Characteristics and Potential Use in Biophotolysis. Appl. Environ. Microbiol. 1979, 37, 454-458. [CrossRef]

9. Bergman, B.; Gallon, J.; Rai, A.; Stal, L.J. N 2 Fixation by non-heterocystous cyanobacteria. FEMS Microbiol. Rev. 1996, 19, 139-185. [CrossRef]

10. Esteves-Ferreira, A.A.; Cavalcanti, J.H.F.; Vaz, M.G.M.V.; Alvarenga, L.V.; Nunes-Nesi, A.; Araújo, W.L. Cyanobacterial nitrogenases: Phylogenetic diversity, regulation and functional predictions. Genet. Mol. Biol. 2017, 40, 261-275. [CrossRef]

11. Janson, S.; Carpenter, E.J.; Bergman, B. Compartmentalisation of nitrogenase in a non-heterocystous cyanobacterium: Trichodesmium contortum. FEMS Microbiol. Lett. 1994, 118, 9-14. [CrossRef]

12. Fredriksson, C.; Bergman, B. Nitrogenase quantity varies diurnally in a subset of cells within colonies of the non-heterocystous cyanobacteria Trichodesmium spp. Microbiology 1995, 141, 2471-2478. [CrossRef]

13. Sciuto, K.; Moro, I. Detection of the new cosmopolitan genus Thermoleptolyngbya (Cyanobacteria, Leptolyngbyaceae) using the 16S rRNA gene and 16S-23S ITS region. Mol. Phylogenet. Evol. 2016, 105, 15-35. [CrossRef] [PubMed]

14. Tang, J.; Li, L.; Li, M.; Du, L.; Waleron, M.; Waleron, M.; Waleron, K.; Daroch, M. Description, taxonomy, and comparative genomics of a novel Thermoleptolyngby strain isolated from hot springs of Ganzi, Sichuan China. BioRxiv 2021. [CrossRef]

15. Yoon, K.S.; Nguyen, N.T.; Tran, K.T.; Tsuji, K.; Ogo, S. Nitrogen fixation genes and nitrogenase activity of the non-heterocystous cyanobacterium Thermoleptolyngbya sp. O-77. Microbes Environ. 2017, 32, 324-329. [CrossRef] [PubMed]

16. Alcorta, J.; Alarcón-Schumacher, T.; Salgado, O.; Díez, B. Taxonomic Novelty and Distinctive Genomic Features of Hot Spring Cyanobacteria. Front. Genet. 2020, 11. [CrossRef] [PubMed]

17. Tang, J.; Jiang, D.; Luo, Y.; Liang, Y.; Li, L.; Shah, M.M.R.; Daroch, M. Potential new genera of cyanobacterial strains isolated from thermal springs of western Sichuan, China. Algal Res. 2018, 31, 14-20. [CrossRef]

18. Liang, Y.; Tang, J.; Luo, Y.; Kaczmarek, M.B.; Li, X.; Daroch, M. Thermosynechococcus as a thermophilic photosynthetic microbial cell factory for $\mathrm{CO}_{2}$ utilisation. Bioresour. Technol. 2019, 278, 255-265. [CrossRef]

19. Riaz, S.; Xiao, M.; Chen, P.; Li, M.; Cui, Y.; Darocha, M. The Genome Copy Number of the Thermophilic Cyanobacterium Thermosynechococcus elongatus E542 Is Controlled by Growth Phase and Nutrient Availability. Appl. Environ. Microbiol. 2021, 87, 1-13. [CrossRef]

20. Goris, J.; Konstantinidis, K.T.; Klappenbach, J.A.; Coenye, T.; Vandamme, P.; Tiedje, J.M. DNA-DNA hybridization values and their relationship to whole-genome sequence similarities. Int. J. Syst. Evol. Microbiol. 2007, 57, 81-91. [CrossRef] [PubMed]

21. Kumar, S.; Stecher, G.; Li, M.; Knyaz, C.; Tamura, K. MEGA X: Molecular evolutionary genetics analysis across computing platforms. Mol. Biol. Evol. 2018, 35, 1547-1549. [CrossRef]

22. Tang, J.; Bromfield, E.S.P.; Rodrigue, N.; Cloutier, S.; Tambong, J.T. Microevolution of symbiotic Bradyrhizobium populations associated with soybeans in east North America. Ecol. Evol. 2012, 2, 2943-2961. [CrossRef] [PubMed]

23. Stanier, R.Y.; Kunisawa, R.; Mandel, M.; Cohen-Bazire, G. Purification and properties of unicellular blue-green algae (order Chroococcales). Bacteriol. Rev. 1971, 35, 171-205. [CrossRef] [PubMed]

24. Chen, Y.B.; Dominic, B.; Mellon, M.T.; Zehr, J.P. Circadian rhythm of nitrogenase gene expression in the diazotrophic filamentous nonheterocystous cyanobacterium Trichodesmium sp. strain IMS 101. J. Bacteriol. 1998, 180, 3598-3605. [CrossRef] [PubMed]

25. Esteves-Ferreira, A.A.; Inaba, M.; Fort, A.; Araújo, W.L.; Sulpice, R. Nitrogen metabolism in cyanobacteria: Metabolic and molecular control, growth consequences and biotechnological applications. Crit. Rev. Microbiol. 2018, 44, 541-560. [CrossRef] [PubMed]

26. Fredriksson, C.; Malin, G.; Siddiqui, P.J.A.; Bergman, B. Aerobic nitrogen fixation is confined to a subset of cells in the nonheterocystous cyanobacterium Symploca PCC 8002. New Phytol. 1998, 140, 531-538. [CrossRef]

27. Berrendero, E.; Valiente, E.F.; Perona, E.; Gómez, C.L.; Loza, V.; Munõz-Martín, M.Á.; Mateo, P. Nitrogen fixation in a nonheterocystous cyanobacterial mat from a mountain river. Sci. Rep. 2016, 6, 1-13. [CrossRef]

28. Li, Z.; Yu, J.; Kim, K.R.; Brand, J. Nitrogen fixation by a marine non-heterocystous cyanobacterium requires a heterotrophic bacterial consort. Environ. Microbiol. 2010, 12, 1185-1193. [CrossRef]

29. Ohki, K.; Fujita, Y. Aerobic nitrogenase activity measured as acetylene reduction in the marine non-heterocystous cyanobacterium Trichodesmium spp. grown under artificial conditions. Mar. Biol. 1988, 98, 111-114. [CrossRef] 